\title{
Erratum
}

\section{Erratum to "Synergistic Effect of Garcinol and Curcumin on Antiproliferative and Apoptotic Activity in Pancreatic Cancer Cells"}

\author{
Mansi A. Parasramka and Smiti Vaid Gupta $\mathbb{D}$ \\ Department of Nutrition and Food Science, College of Liberal Arts and Sciences, Wayne State University, 3009 Science Hall, \\ Detroit, MI 48201, USA \\ Correspondence should be addressed to Smiti Vaid Gupta; sgupta@wayne.edu \\ Received 25 June 2019; Accepted 25 June 2019; Published 15 July 2019 \\ Copyright (C) 2019 Mansi A. Parasramka and Smiti Vaid Gupta. This is an open access article distributed under the Creative \\ Commons Attribution License, which permits unrestricted use, distribution, and reproduction in any medium, provided the \\ original work is properly cited.
}

\begin{abstract}
In the article titled "Synergistic Effect of Garcinol and Curcumin on Antiproliferative and Apoptotic Activity in Pancreatic Cancer Cells" [1], the panel in Figure 3 showing BxPC-3 with garcinol:curcumin in a 1:4 ratio was duplicated as the panel showing Panc-1 with garcinol:curcumin in a 1:4 ratio, due to an error during the production process. The corrected Figure is shown below:
\end{abstract}



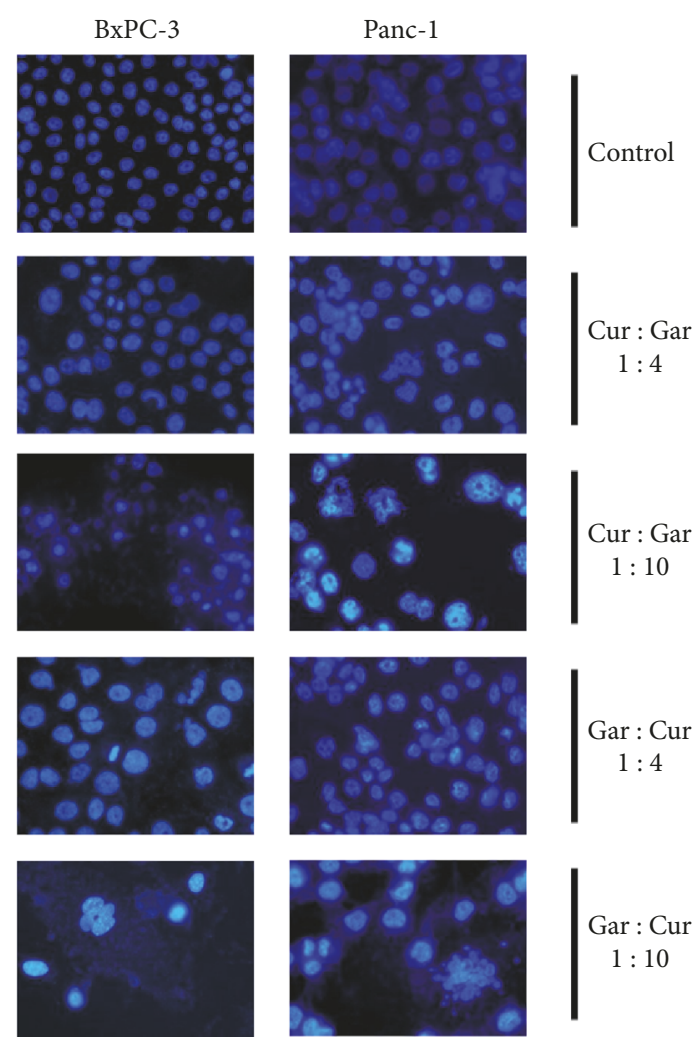

Figure 3: Apoptotic morphological changes such as abnormal nuclear morphology, reduction in cell number with apoptotic body formation, and cell shrinkage induced by combination treatment with curcumin and garcinol in different ratios for 48 hours were observed using DAPI stain in both PaCa cell lines: BxPC-3 (left panel) and Panc-1 (right panel) (1:4 ratio is $2.5 \mu \mathrm{M}: 10 \mu \mathrm{M}$ concentration and $1: 10$ ratio is $2 \mu \mathrm{M}: 20 \mu \mathrm{M}$ respective concentrations).

\section{References}

[1] M. A. Parasramka and S. V. Gupta, "Synergistic effect of garcinol and curcumin on antiproliferative and apoptotic activity in pancreatic cancer cells," Journal of Oncology, vol. 2012, Article ID 709739, 8 pages, 2012. 


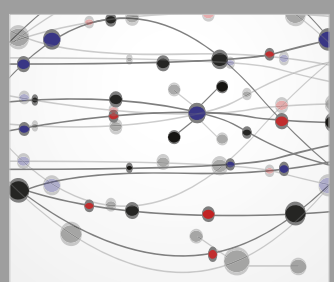

The Scientific World Journal
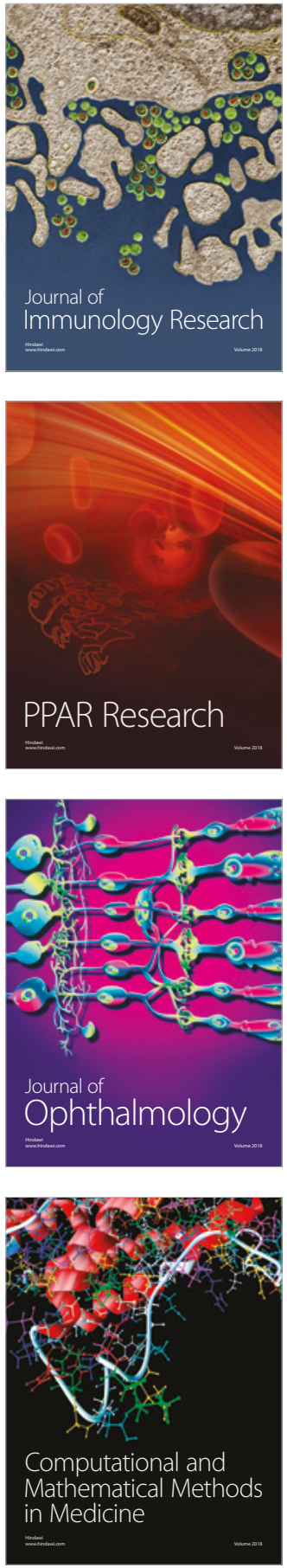

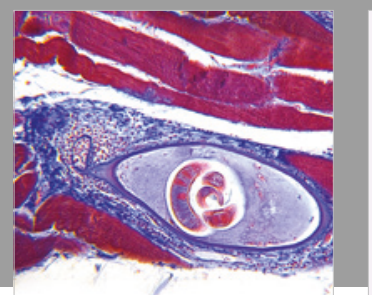

Gastroenterology Research and Practice

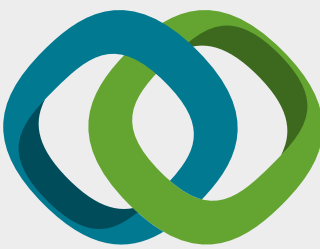

\section{Hindawi}

Submit your manuscripts at

www.hindawi.com
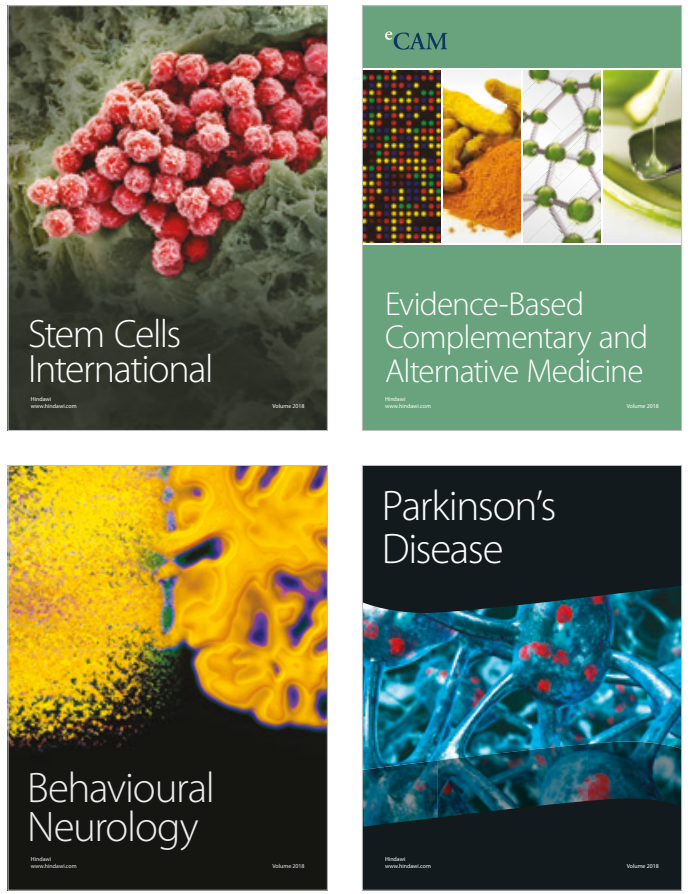

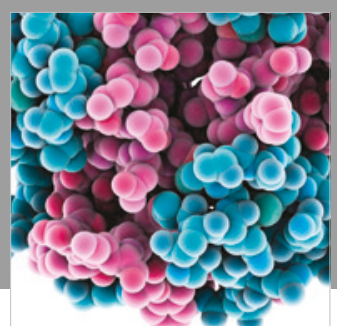

ournal of

Diabetes Research

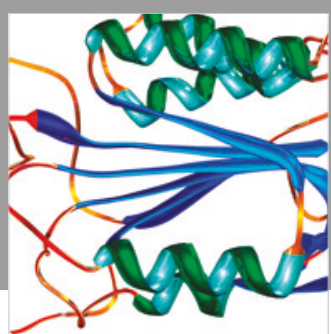

Disease Markers
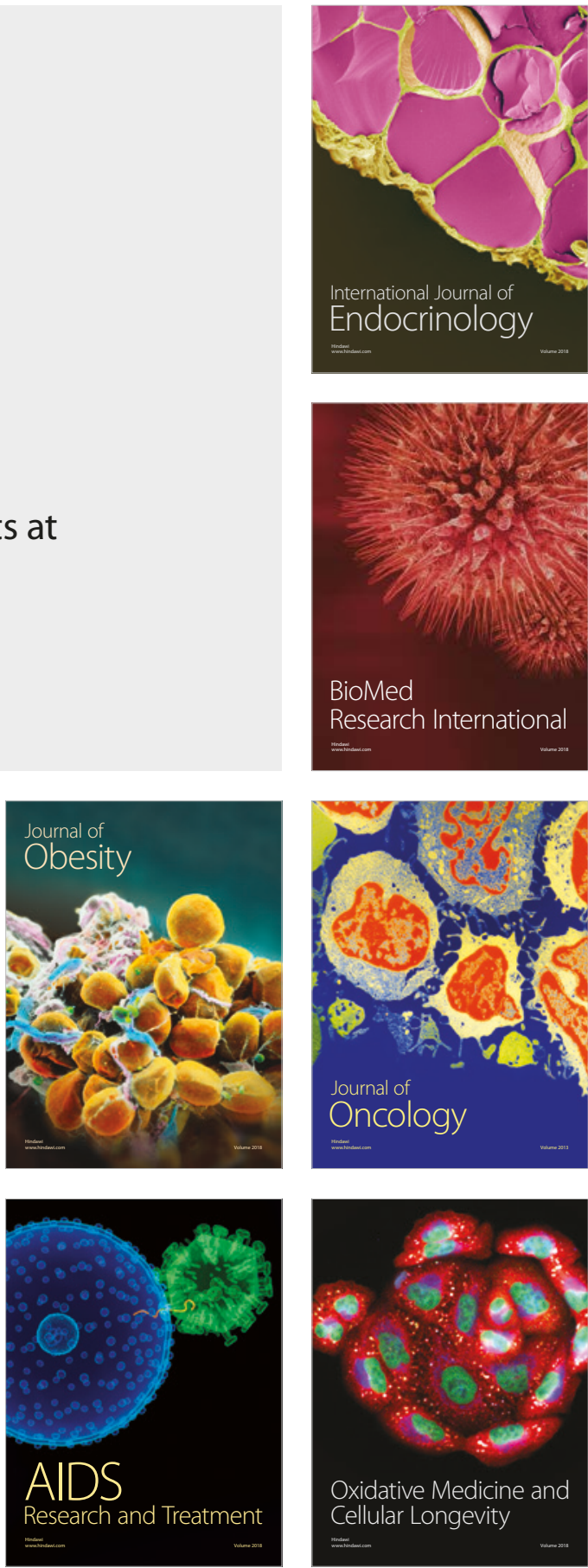